\title{
Characteristics of Breast Masses of Female Patients Referred for Diagnostic Breast Ultrasound from a Saudi Primary Health Care Setting
}

This article was published in the following Dove Press journal: International Journal of General Medicine

\author{
Nouf A AIShamlan $\mathbb{D}^{\prime}$ \\ Reem S AIOmar (D) \\ Omar Y Almukhadhib ${ }^{2}$ \\ Saad A Algarni ${ }^{2}$ \\ Askar K Alshaibani ${ }^{2}$ \\ Sara A Elmaki ${ }^{3}$ \\ Malak A Al Shammari (D') \\ Abdulaziz M Sebiany (D) \\ 'Department of Family and Community \\ Medicine, Imam Abdulrahman Bin Faisal \\ University, Dammam, Saudi Arabia; \\ ${ }^{2}$ College of Medicine, Imam Abdulrahman \\ Bin Faisal University, Dammam, Saudi \\ Arabia; ${ }^{3}$ Department of Radiology at \\ Family and Community Medicine Center, \\ Imam Abdulrahman Bin Faisal University, \\ Dammam, Saudi Arabia
}

Background: Breast masses are common among females presenting to primary health care (PHC) facilities. The family physician's role is crucial in detecting breast disease. Utilization of breast ultrasonography has been increasing recently as a diagnostic tool.

Objective: This study aims to determine the characteristics of masses detected on breast ultrasound, their associations with characteristics of females attending the PHC setting and explore the management of these cases by family physicians.

Methods: This registered based, cross-sectional study included 321 females who were referred for diagnostic breast ultrasound in the PHC center of the University hospital, Eastern province, Saudi Arabia (2017-2019). $t$-test, Chi-squared and Fisher's Exact tests were performed to assess associations between the presence of breast masses in the ultrasound and patients' characteristics. Moreover, to compare the breast masses in two groups of patients $(<40$ years and $\geq 40$ years) regarding their characteristics, ultrasound findings, and further management performed. $\mathrm{P}<0.05$ was considered statistically significant.

Results: Approximately $24 \%$ patients had a breast mass and $70.92 \%$ of cases were detected among females $\geq 40$ years old. The odds of having a breast mass were highest among overweight, females complaining from a breast lump, and who had early menarche. Grand multiparous had lower odds of a breast mass. Females $<40$ years old had higher rates of breastfeeding, increasing parity, and obesity than older females. Sonographic examined masses were larger in young females, and posterior enhancement of the mass was more reported in older. BI-RADs of the masses were not associated with the patient's age.

Conclusion: Breast masses were prevalent among females who underwent breast ultrasound. The results support referral for investigation when a female complains of a breast lump. Family physicians have a vital role in encouraging protective behaviors from developing breast masses such as maintaining normal weight and breastfeeding.

Keywords: breast, mass, ultrasound, primary care, family physician

\section{Introduction}

Family physicians are at the frontline of the healthcare system; many patient complaints are initially evaluated in the primary health care (PHC) setting. Breast problems account for frequent complaints among females presenting in PHC settings. The mean number of visits to the general practitioners (GPs) in the United Kingdom due to breast symptoms was approximately 2.1 to 3.5 each month. Although most cases reported to GPs are benign, especially in young females, they can be associated with high levels of anxiety for possible malignancy. ${ }^{1}$ A study
Correspondence: Nouf A AlShamlan Department of Family and Community Medicine, Imam Abdulrahman Bin Faisal University, Dammam, Saudi Arabia Tel +966504901406

Email nashamlan@iau.edu.sa
International Journal of General Medicine 202I:|4 755-763

submit your manuscript

(c) (i) (5) 2021 Alshamlan et al. This work is published and licensed by Dove Medical Press Limited. The full terms of this license are available at https://www.dovepress.com/ (c) ${ }_{\mathrm{BY}}$ NC terms.php and incorporate the Creative Commons Attribution - Non Commercial (unported, v3.0) License (http://creativecommons.org/licenses/by-nc/3.0/). By accessing the work you hereby accept the Terms. Non-commercial uses of the work are permitted without any further permission from Dove Medical Press Limited, provided the work is properly attributed. For permission for commercial use of this work, please see paragraphs 4.2 and 5 of our Terms (https://www.dovepress.com/terms.php). 
conducted among females who visited the Dutch family medicine offices between 1985 and 2003 revealed that 3\% of females presented with a breast-related symptom, and among those females, most complaints were breast pain followed by a palpable lump. ${ }^{1}$

Breast ultrasonography has been increasingly used recently as diagnostic imaging for breast diseases. Since the risk of radiation is low, it is considered safe for use in pregnant and breastfeeding women. According to a study in Iran among 203 females aged between 16 and 87 years, ultrasound was found to have high sensitivity, specificity, and positive and negative predictive values for the detection of benign and malignant breast lesions and high diagnostic accuracy for palpable breast masses. ${ }^{2}$ Ultrasound is the imaging of choice for evaluations of breast masses among females younger than 30 years, and it can be used in combination with other investigations, such as mammography, in older females. ${ }^{3}$ Certain sonographic characteristics of breast masses were crucial to be described and reported to differentiate between benign and malignant diagnoses such as echogenicity, dimensions, margins, increase in vascularity, and the presence or absence of calcification., ${ }^{2,4}$ The Breast Imaging Reporting and Data System (BI-RADS) is a classification that was developed by the American College of Radiology to unify the interpretation of breast findings from ultrasound and mammography. It has seven main classes; these are designated as 0 to 6 represented levels of; needing further assessment, negative, benign, probably benign, suspicious, highly suspicious findings, and biopsy-proven malignancy, respectively. ${ }^{5,6}$ The front line's role in family medicine is crucial in the management process of breast diseases especially in detecting the highly suspicious lesions early.

Breast cancer is a public health problem worldwide. In the Kingdom of Saudi Arabia (KSA), it is the most common type of cancer among females according to a national report released in 2014. ${ }^{7}$ KSA and other Gulf countries had major changes in the social and cultural lifestyles of their citizens within the last two decades. Furthermore, the incidence of communicable diseases decreased, while that of non-communicable diseases, such as breast cancer, increased. Consequently, policymakers in these countries recommend early detection and diagnosis for such highrisk populations. ${ }^{8}$ In KSA, screening mammography is offered to an average risk female aged 40 years and older every 2 years. For high-risk groups, it is recommended annually, at a younger age, in addition to other investigations such as MRIs. ${ }^{9,10}$ Screening services are provided freely in the governmental healthcare settings. Moreover, the Saudi Ministry of Health, in October of every year, during the International Breast Cancer Awareness Month, conducts national health promotion and awareness campaigns for breast cancer. ${ }^{11}$

Several established factors that are significantly associated with breast cancer in females have been reported in previous studies such as age, early menarche, late menopause, family history, high body mass index (BMI), and history of using hormonal contraception. ${ }^{12,13}$

An extensive literature search revealed that there is a lack of research on the use of ultrasound for the evaluation of breast disorders in PHC settings. In KSA, with the emergence of the 2030 vision, and along with the Ministry of Health's plan which focuses primarily on the PHC setting, and the high incidence of breast cancer in KSA especially in the Eastern region, it becomes imperative to explore this matter. ${ }^{7,14}$ Thus, this study aims to determine the characteristics of masses detected on breast ultrasound, their associations with sociodemographic and clinical characteristics of females attending a PHC center in the Eastern Province of KSA. As well as to explore the management of these cases by the family physicians.

\section{Patients and Methods}

This registered based, cross-sectional study was conducted at the PHC center of Imam Abdulrahman Bin Faisal University (IAU) in the Eastern province of KSA. Inclusion criteria included females of all ages who were referred for diagnostic breast ultrasound between January 2017 and December 2019 through a full coverage sample $(\mathrm{N}=321)$. The data excluded male patients. The PHC center at IAU was established in 2016, and the Radiology Department was launched in 2017. This PHC center provides care to the university faculty, staff, students, and their families as well as residents in the catchment area. Besides family medicine clinics, this center has a laboratory, pharmacy, radiology department, urgent care services, and other specialized clinics. Ethical approval was obtained from the Institutional Review Board committee of IAU. Patient information was kept confidential and anonymous, and it was not used for any purpose other than research. Patient informed consent was not required, as the data was anonymized.

Data on sociodemographic characteristics, clinical presentation, breast ultrasound findings, and patient risk factors for breast cancer were collected through a researcherdesigned checklist after reviewing similar studies., ${ }^{2,12,15}$ 
Moreover, histopathological results were also reported, if performed. The authors collected the data by filling the checklists at the PHC center of IAU between January and March 2020. Patient records are electronic in this PHC center. Referrals by family physicians to the breast surgery clinic and for mammography, MRI, and biopsy were accessed from the same electronic record system. The BMI $\left(\mathrm{kg} / \mathrm{m}^{2}\right)$ of participants was recorded in their electronic record at the time of their presentation. BMIs $<18.5 \mathrm{~kg} / \mathrm{m}^{2}$, $18.5-24.9 \mathrm{~kg} / \mathrm{m}^{2}, 25-29.9 \mathrm{~kg} / \mathrm{m}^{2}$, and $>30 \mathrm{~kg} / \mathrm{m}^{2}$ were classified as underweight, normal weight, overweight, and obese, respectively. ${ }^{12}$ The data collection sheet was revised for content validity by three professional experts. The ultrasound was performed by a radiology consultant experienced in breast imaging.

\section{Data Analysis}

Data were analyzed using Stata statistical software V.15 (Stata Corp, College Station, TX, USA). ${ }^{16}$ For descriptive statistics, frequencies and percentages were used for categorical variables, while means and standard deviations (SD) were used for continuous variables after checking the normality of the data by using the Shapiro-Wilk test.

The chi-square or the Fisher's exact test and the Student's $t$-test were used to assess associations between the presence of breast masses in the ultrasound and patients' characteristics. Moreover, to compare the breast masses in two groups of patients $(<40$ years and $\geq 40$ years) regarding their characteristics, ultrasound findings, and further management performed in form of a referral to a breast surgery clinic, and further investigations. $\mathrm{P}<0.05$ was considered statistically significant. Binary logistic regression analysis was performed to account for possible confounders, and odds ratios (ORs) with $95 \%$ confidence intervals (CIs) were reported. Model fit diagnostics, including residual analyses, were performed to determine the best model fit. The model that minimized the Akaike and the Bayesian information criteria was chosen.

\section{Results}

A total of 321 females were included in the study. Of them, 77 patients (23.99\%) had breast masses. The patients' sociodemographic and clinical data in relation to the presence of a breast mass on ultrasound are outlined in Table 1. The mean age was 31.42 years $(\mathrm{SD} \pm 10.48)$ for
Table I Sociodemographic and Clinical Characteristics of Females Who Performed Breast Ultrasonography Between January 2017 and December 2019 in a Primary Health Care Center, Saudi Arabia $(\mathrm{n}=32 \mathrm{I})$

\begin{tabular}{|c|c|c|c|}
\hline \multirow[t]{2}{*}{ Clinical Characteristics } & \multicolumn{2}{|c|}{ Breast Mass } & \multirow[t]{2}{*}{ P-value } \\
\hline & $\begin{array}{c}\text { Absence } \\
\text { N (\%) } \\
244 \text { (76.01) }\end{array}$ & $\begin{array}{c}\text { Presence } \\
\text { N (\%) } \\
77(23.99)\end{array}$ & \\
\hline $\mathbf{A g e}^{\mathrm{a}}$ & $34.64 \pm 12.26$ & $31.42 \pm 10.48$ & 0.04 \\
\hline $\begin{array}{l}\text { Origin } \\
\text { Gulf } \\
\text { Arab } \\
\text { African } \\
\text { Asian } \\
\text { European }\end{array}$ & $\begin{array}{l}182(74.59) \\
33(13.52) \\
04(01.64) \\
24(09.84) \\
01(00.4 I)\end{array}$ & $\begin{array}{l}61(79.22) \\
07(09.09) \\
02(02.60) \\
07(09.09) \\
0\end{array}$ & 0.77 \\
\hline $\begin{array}{l}\text { Body mass index } \\
\text { Underweight } \\
\text { Normal weight } \\
\text { Overweight } \\
\text { Obese }\end{array}$ & $\begin{array}{l}04(01.64) \\
107(43.85) \\
72(29.51) \\
61(25.00)\end{array}$ & $\begin{array}{l}01(01.30) \\
20(25.97) \\
34(44.16) \\
22(28.57)\end{array}$ & 0.02 \\
\hline $\begin{array}{l}\text { Clinical presentation } \\
\text { Asymptomatic } \\
\text { Lump } \\
\text { Breast pain } \\
\text { Nipple complaints } \\
\text { Combined presentation }\end{array}$ & $\begin{array}{l}20(08.20) \\
80(32.79) \\
94(38.52) \\
14(05.14) \\
36(14.75)\end{array}$ & $\begin{array}{c}01(01.30) \\
49(63.64) \\
10(12.99) \\
0 \\
17(22.08)\end{array}$ & $<0.001$ \\
\hline $\begin{array}{l}\text { Site of complaint } \\
\text { Left } \\
\text { Right } \\
\text { Bilateral }\end{array}$ & $\begin{array}{l}102(45.33) \\
70(31.11) \\
53(23.56)\end{array}$ & $\begin{array}{l}36(47.37) \\
26(34.21) \\
14(18.42)\end{array}$ & 0.63 \\
\hline $\begin{array}{l}\text { Menopausal status } \\
\text { Premenopausal } \\
\text { Postmenopausal }\end{array}$ & $\begin{array}{c}218(89.34) \\
26(10.66)\end{array}$ & $\begin{array}{l}73(94.81) \\
04(05.19)\end{array}$ & 0.10 \\
\hline $\begin{array}{l}\text { History of using } \\
\text { hormonal } \\
\text { contraception } \\
\text { No } \\
\text { Yes }\end{array}$ & $\begin{array}{l}142(58.20) \\
102(41.80)\end{array}$ & $\begin{array}{l}49(63.64) \\
28(36.36)\end{array}$ & 0.39 \\
\hline $\begin{array}{l}\text { History of } \\
\text { breastfeeding } \\
\text { No } \\
\text { Yes }\end{array}$ & $\begin{array}{l}\text { I0I (4I.39) } \\
\text { I43 (58.6I) }\end{array}$ & $\begin{array}{l}42(54.55) \\
35(45.45)\end{array}$ & 0.04 \\
\hline $\begin{array}{l}\text { Parity } \\
\text { Nulliparous } \\
\text { Primiparous } \\
\text { Multiparous } \\
\text { Grand multiparous }\end{array}$ & $\begin{array}{l}89(36.48) \\
23(09.43) \\
92(37.70) \\
40(16.39)\end{array}$ & $\begin{array}{l}37(48.05) \\
08(10.39) \\
28(36.36) \\
04(05.19)\end{array}$ & 0.04 \\
\hline
\end{tabular}

(Continued) 
Table I (Continued).

\begin{tabular}{|c|c|c|c|}
\hline \multirow[t]{2}{*}{ Clinical Characteristics } & \multicolumn{2}{|c|}{ Breast Mass } & \multirow[t]{2}{*}{ P-value } \\
\hline & $\begin{array}{c}\text { Absence } \\
\text { N (\%) } \\
244(76.01)\end{array}$ & $\begin{array}{c}\text { Presence } \\
\text { N (\%) } \\
77(23.99)\end{array}$ & \\
\hline $\begin{array}{l}\text { Hormonal replacement } \\
\text { therapy } \\
\text { No } \\
\text { Yes }\end{array}$ & $\begin{array}{c}239(97.95) \\
05(02.05)\end{array}$ & $\begin{array}{l}75(97.40) \\
02(02.60)\end{array}$ & 0.67 \\
\hline $\begin{array}{l}\text { Family history of } \\
\text { cancer } \\
\text { No } \\
\text { Yes }\end{array}$ & $\begin{array}{l}12 \mathrm{I}(49.79) \\
122(50.2 \mathrm{I})\end{array}$ & $\begin{array}{l}37(48.05) \\
40(51.95)\end{array}$ & 0.81 \\
\hline $\begin{array}{l}\text { Age of menarche } \\
<12 \text { years old } \\
\text { Between } 12 \text { and } 13 \text { years } \\
\quad \text { old } \\
\geq 14 \text { years old }\end{array}$ & $\begin{array}{l}34(13.93) \\
14 \mid(57.79) \\
69(28.28)\end{array}$ & $\begin{array}{l}12(15.58) \\
44(57.14) \\
21(27.27)\end{array}$ & 0.90 \\
\hline
\end{tabular}

Note: ${ }^{\text {a } D a t a ~ a r e ~ p r e s e n t e d ~ a s ~ m e a n ~} \pm$ SD

females presenting with a breast mass and 34.64 years (SD \pm 12.26 ) for those without a mass. Most patients who did not have a breast mass had a normal BMI (43.85\%), while most of those who had were overweight (44.16\%). With regards to the most common clinical presentation, it was found that among females with a breast mass, 63.64\% complained of a lump, while among females without a mass, $38.52 \%$ complained of breast pain. Of the patients who had a mass, $54.55 \%$ denied any history of breastfeeding and $48.05 \%$ were nulliparous.

Table 2 demonstrated the differences between two groups of patients' ages $(<40$ years and $\geq 40)$ regarding their sociodemographic and clinical characteristics. Most of the younger females were obese $(42.42 \%)$, on the other hand, most older patients had normal BMI (45.95\%). Females younger than 40 years old had a significantly higher rate of using hormonal contraception (59.60\%), breastfeeding $(82.83 \%)$, and high parity in comparison to females $\geq 40$ years old.

The findings of the binary logistic regression analysis of the predictors of breast masses for the participants are presented in Table 3. Independent predictors of breast masses on ultrasound were being overweight (OR, 3.32; 95\% CI, 1.62-6.81) and obese (OR, 2.61; 95\% CI, 1.175.83). The odds were high in patients complaining of breast lumps (OR, 10.44; 95\% CI, 1.21-18.97). Early
Table 2 Sociodemographic and Clinical Characteristics of Females by Age $(n=321)$

\begin{tabular}{|c|c|c|c|}
\hline \multirow[t]{2}{*}{ Clinical Characteristics } & \multicolumn{2}{|c|}{ Age Group } & \multirow[t]{2}{*}{ P-value } \\
\hline & $\begin{array}{c}<40 \\
\text { Years } \\
N(\%) \\
99(30.84)\end{array}$ & $\begin{array}{c}\geq 40 \text { Years } \\
\text { N (\%) } \\
222 \\
(69.16)\end{array}$ & \\
\hline Origin & & & 0.21 \\
\hline Gulf & $72(72.73)$ & I7I (77.03) & \\
\hline Arab & $10(10.10)$ & $30(|3.5|)$ & \\
\hline African & $02(02.02)$ & $04(01.80)$ & \\
\hline Asian & $15(15.15)$ & $16(07.21)$ & \\
\hline European & 0 & $0 \mathrm{OI}(0.45)$ & \\
\hline Body mass index & & & $<0.001$ \\
\hline Underweight & 0 & $05(02.25)$ & \\
\hline Normal weight & $25(25.25)$ & $102(45.95)$ & \\
\hline Overweight & $32(32.32)$ & $74(33.33)$ & \\
\hline Obese & $42(42.42)$ & $41(18.47)$ & \\
\hline Clinical presentation & & & $<0.001$ \\
\hline Asymptomatic & $15(15.15)$ & $06(02.70)$ & \\
\hline Lump & 37 (37.37) & $92(4 I .44)$ & \\
\hline Breast pain & $27(27.27)$ & 77 (34.68) & \\
\hline Nipple complaints & $03(03.03)$ & II (04.95) & \\
\hline Combined presentation & $17(17.17)$ & $36(16.22)$ & \\
\hline Site of complaint & & & 0.73 \\
\hline Left & $37(43.53)$ & I0I (46.76) & \\
\hline Right & $30(35.29)$ & $66(30.56)$ & \\
\hline Bilateral & $18(21.18)$ & 49 (22.69) & \\
\hline $\begin{array}{l}\text { History of using } \\
\text { hormonal contraception }\end{array}$ & & & $<0.001$ \\
\hline No & $40(40.40)$ & 151 (68.02) & \\
\hline Yes & $59(59.60)$ & 71 (31.98) & \\
\hline History of breastfeeding & & & $<0.001$ \\
\hline No & $17(17.17)$ & $126(56.76)$ & \\
\hline Yes & $82(82.83)$ & $96(43.24)$ & \\
\hline Parity & & & $<0.001$ \\
\hline Nulliparous & $13(13.13)$ & $113(50.90)$ & \\
\hline Primiparous & $08(08.08)$ & $23(10.36)$ & \\
\hline Multiparous & $44(44.44)$ & $76(34.23)$ & \\
\hline Grand multiparous & $34(34.34)$ & $10(04.50)$ & \\
\hline Family history of cancer & & & 0.60 \\
\hline No & $51(51.52)$ & $108(48.64)$ & \\
\hline Yes & $48(48.48)$ & $114(51.35)$ & \\
\hline Age of menarche & & & 0.91 \\
\hline$<12$ years old & $16(16.16)$ & $39(17.57)$ & \\
\hline $\begin{array}{l}\text { Between } 12 \text { and } 13 \text { years } \\
\text { old }\end{array}$ & $56(56.57)$ & $120(54.05)$ & \\
\hline$\geq 14$ years old & $27(27.27)$ & $63(28.38)$ & \\
\hline
\end{tabular}


Table 3 Unadjusted and Adjusted Odds Ratios of Breast Mass on Ultrasonography $(n=321$ )

\begin{tabular}{|c|c|c|c|c|}
\hline \multirow[t]{3}{*}{ Clinical Characteristics } & \multicolumn{4}{|c|}{ Presence of Breast Mass } \\
\hline & \multicolumn{2}{|c|}{ Unadjusted } & \multicolumn{2}{|c|}{ Adjusted } \\
\hline & OR & $95 \% \mathrm{Cl}$ & OR & $95 \% \mathrm{Cl}$ \\
\hline Age & 00.97 & $00.94-00.99$ & 00.99 & $00.95-01.03$ \\
\hline \multicolumn{5}{|l|}{ Body mass index } \\
\hline Underweight & 01.33 & $00.14-12.59$ & 0.54 & $00.04-06.66$ \\
\hline Normal weight & Reference & Reference & Reference & Reference \\
\hline Overweight & 02.52 & $01.34-04.73$ & 03.32 & $01.62-06.8 \mathrm{I}$ \\
\hline Obese & 01.92 & $00.97-03.81$ & 02.61 & $01.17-05.83$ \\
\hline \multicolumn{5}{|l|}{ Clinical presentation } \\
\hline Asymptomatic & Reference & Reference & Reference & Reference \\
\hline Lump & 12.24 & $01.59-19.17$ & 10.44 & $01.21-18.97$ \\
\hline Breast pain & 02.12 & $00.25-17.57$ & 1.53 & $00.17-14.05$ \\
\hline Nipple complaints ${ }^{\mathrm{a}}$ & - & - & - & - \\
\hline Combined presentation & 09.44 & $01.16-17.32$ & 06.72 & $00.75-15.98$ \\
\hline \multicolumn{5}{|l|}{ Parity } \\
\hline Nulliparous & Reference & Reference & Reference & Reference \\
\hline Primiparous & 00.83 & $00.34-02.03$ & 00.85 & $00.30-02.44$ \\
\hline Multiparous & 00.73 & $00.41-01.29$ & 00.82 & $00.35-01.90$ \\
\hline Grand multiparous & 00.24 & $00.08-00.72$ & 00.20 & $00.05-00.81$ \\
\hline \multicolumn{5}{|l|}{ Age of menarche } \\
\hline$<12$ years old & 02.48 & $01.28-04.80$ & 02.29 & $01.05-04.97$ \\
\hline Between 12 and 13 years old & Reference & Reference & Reference & Reference \\
\hline$\geq 14$ years old & 01.22 & $00.66-02.26$ & 01.22 & $00.60-02.48$ \\
\hline \multicolumn{5}{|l|}{ Menopausal status } \\
\hline Premenopausal & Reference & Reference & Reference & Reference \\
\hline Postmenopausal & 00.45 & $00.15-01.36$ & $00.4 I$ & $0.07-02.14$ \\
\hline
\end{tabular}

Note: a No participants with nipple complaints showed a breast mass on ultrasonography. Abbreviations: $\mathrm{OR}$, odds ratio; $\mathrm{Cl}$, confidence interval.

menarche, before the age of 12 years, was associated with the highest significant risk of breast masses (OR, 2.29; 95\% CI, 1.05-4.97) in comparison with older age menarche. Grand multiparous participants had lower odds of having breast masses (OR, 0.20; 95\% CI, 0.05-0.81).

The majority of breast masses (70.92\%) were detected among females $\geq 40$ years old. The dimensions of the masses were larger in younger females. In both age groups, the most common location of the mass was overlapping followed by upper outer quadrant. Posterior enhancement of the mass was seen more common in older females $(86.67 \%)(\mathrm{P}=0.01)$. The difference between female's age groups and BI-RADS of the masses was not statistically significant. Similarly, no other statistically significant ultrasonographic characteristics of breast masses were seen in Table 4.
Family physicians referred $64.71 \%$ of younger aged cases and all females $\geq 40$ years old with breast masses for mammography $(\mathrm{P}<0.001)$. Referrals to the breast clinic, MRI, biopsy, and surgical removal of the masses were not statistically different between both age groups. (Table 5).

Among the 77 females with a breast mass, 12 underwent biopsy. Benign lesions were found in 10 of these patients while 2 had malignant lesions. Surgical removal of the masses was performed on 9 patients. Pathology examination of surgically removed specimens showed benign findings in 7 patients ( $\geq 40$ years); one case had fibrocystic changes and the other cases had fibroadenoma, and malignant findings in 2 patients; both had invasive ductal carcinoma. The rest of the patients were followed according to their BI-RADS categories. 
Table 4 Ultrasonographic Characteristics of Breast Masses Among Females in a Primary Health Care Center, Saudi Arabia $(n=77)$

\begin{tabular}{|c|c|c|c|}
\hline \multirow{2}{*}{$\begin{array}{l}\text { Ultrasonography } \\
\text { Characteristics of } \\
\text { Masses }\end{array}$} & \multicolumn{2}{|c|}{ Age Group } & \multirow[t]{2}{*}{ P-value } \\
\hline & $\begin{array}{c}<40 \\
\text { Years } \\
N(\%) \\
17(22.08)\end{array}$ & $\begin{array}{c}\geq 40 \\
\text { Years } \\
\text { N (\%) } \\
\mathbf{6 0}(\mathbf{7 0 . 9 2 )}\end{array}$ & \\
\hline Number of masses & & & 0.27 \\
\hline One & $13(76.47)$ & $33(55.00)$ & \\
\hline Two & $02(11.76)$ & $15(25.00)$ & \\
\hline Multiple & $02(11.76)$ & $12(20.00)$ & \\
\hline Size AP in $\mathrm{cm}^{\mathbf{a}}$ & $1.25 \pm 0.82$ & $0.87 \pm 0.62$ & 0.09 \\
\hline Size $\mathbf{T}$ in $\mathrm{cm}^{\mathbf{a}}$ & $2.05 \pm 1.30$ & $0.79 \pm 0.21$ & 0.04 \\
\hline Mass site & & & 0.02 \\
\hline Overlapping lesions & $06(35.29)$ & $34(56.67)$ & \\
\hline Lower inner quadrant & 이 (05.88) & $04(06.67)$ & \\
\hline Lower outer quadrant & 이 (05.88) & $04(06.67)$ & \\
\hline Upper inner quadrant & $04(23.53)$ & $0 \mathrm{OI}(0 \mathrm{I} .67)$ & \\
\hline Upper outer quadrant & $05(29.4 I)$ & $17(28.33)$ & \\
\hline Site of mass & & & 0.48 \\
\hline Left breast & $08(47.06)$ & $34(56.67)$ & \\
\hline Right breast & $09(52.94)$ & $26(43.33)$ & \\
\hline Mass margins & & & 0.79 \\
\hline III-defined & $03(17.65)$ & $09(15.00)$ & \\
\hline Well-defined & $14(82.35)$ & $51(85.00)$ & \\
\hline Mass texture & & & 0.30 \\
\hline Heterogenous & $05(29.41)$ & $26(43.33)$ & \\
\hline Homogenous & $12(70.59)$ & $34(56.67)$ & \\
\hline Mass vascularity & & & 0.52 \\
\hline No & $15(88.24)$ & $49(81.67)$ & \\
\hline Yes & $02(11.76)$ & II (I8.33) & \\
\hline Mass calcification & & & 0.65 \\
\hline No & $14(82.35)$ & $52(86.67)$ & \\
\hline Yes & $03(17.65)$ & $08(13.33)$ & \\
\hline Posterior enhancement & & & 0.01 \\
\hline No & $07(4 I .18)$ & $08(13.33)$ & \\
\hline Yes & $10(58.82)$ & $52(86.67)$ & \\
\hline Axillary lymph nodes & & & 0.27 \\
\hline Normal & $17(100.00)$ & $56(93.33)$ & \\
\hline Reactive & 0 & $04(06.67)$ & \\
\hline Mass BI-RADS & & & 0.60 \\
\hline Zero & $05(29.4 I)$ & $10(16.67)$ & \\
\hline Two & $05(29.41)$ & $19(31.67)$ & \\
\hline Three & $06(35.29)$ & $29(48.33)$ & \\
\hline Four & 이 (05.88) & $02(03.33)$ & \\
\hline
\end{tabular}

Note: ${ }^{a}$ Data are presented as mean \pm SD.

Abbreviation: BI-RADS, Breast Imaging Reporting and Data System.

\section{Discussion}

The current study showed that $23.99 \%$ of females who underwent breast ultrasound in the studied PHC center had a breast mass, and about three-quarters of cases were detected among females $\geq 40$ years old. Breast cancer screening in KSA is offered to females 40 years old and above. ${ }^{9,10}$ Therefore, the patients over 40 years old, in theory, should have a negative mammogram, and present to the family physicians with an interval finding. In this context, these two groups of patients $(<40$ years and $\geq 40$ years) were compared in the current study. Although adherence to the screening program was beyond the aim of this study, however, many Saudi studies reported that this service is still underutilized for many reasons such as patients' lack of awareness, fear of results, and other socio-cultural factors which consequently delays the time of diagnosis and affects the prognosis. ${ }^{11,17-19}$

We found that females who complained of breast lumps had higher odds of breast mass detected on ultrasound, and most patients who did not have an ultrasound detected mass complained of breast pain. Literature revealed that breast lumps are the most frequent presenting symptoms among females with breast cancer. ${ }^{20} \mathrm{~A}$ study conducted in the Dutch family medicine offices reported that females who presented with a breast lump had high positive likelihood ratios (LRs) for breast cancer, suggesting that physicians should deal with this symptom aggressively regardless of patient age. Moreover, the positive LRs of breast pain indicative of cancer were the lowest among all other breast symptoms. ${ }^{1}$ A study conducted in Mexico among females who presented to PHC centers with breast symptoms between the years 2006 and 2010 revealed that the most common symptoms were lump (71.7\%) and breast pain (67.7\%), and the most frequent age group was between 20 and 49 years. Moreover, breast lumps had a positive LR of 4.53 (95\% CI, 2.51-8.17) for breast cancer, while breast pain had an elevated negative LR of 1.08 (95\% CI, 1.05-1.11). ${ }^{21}$ The current study showed that the odds of having a breast mass were higher among females with higher BMI and early menarche (before 12 years of age). The literature revealed that these two factors increased the risk of breast cancer among females. ${ }^{12}$ An alarming finding in the current study was that most younger females with breast masses were obese and overweight. An increase in BMI is a global health concern with many medical consequences, 
Table 5 Further Managements of Females with Ultrasound Detected Breast Masses in a Primary Health Care Center, Saudi Arabia, Between January 2017 and December $2019(n=77)$

\begin{tabular}{|c|c|c|c|}
\hline \multirow[t]{2}{*}{ Further Managements } & \multicolumn{2}{|c|}{ Age Group } & \multirow[t]{2}{*}{ P-value } \\
\hline & $\begin{array}{c}<40 \text { Years } \\
N(\%) \\
17(22.08)\end{array}$ & $\begin{array}{c}\geq 40 \text { Years } \\
\quad N(\%) \\
60(70.92)\end{array}$ & \\
\hline $\begin{array}{l}\text { Referral to breast clinic } \\
\text { No } \\
\text { Yes }\end{array}$ & $\begin{array}{l}10(58.82) \\
07(41.18)\end{array}$ & $\begin{array}{l}30(50.00) \\
30(50.00)\end{array}$ & 0.52 \\
\hline $\begin{array}{l}\text { Mammography } \\
\text { No } \\
\text { Yes }\end{array}$ & $\begin{array}{l}06 \text { (35.29) } \\
\text { II (64.7I) }\end{array}$ & $\begin{array}{c}0(0.00) \\
60(100.00)\end{array}$ & $<0.001$ \\
\hline $\begin{array}{l}\text { Breast MRI } \\
\text { No } \\
\text { Yes }\end{array}$ & $\begin{array}{l}\text { I6 (94.12) } \\
01 \text { (05.88) }\end{array}$ & $\begin{array}{l}55(91.67) \\
05(08.33)\end{array}$ & 0.73 \\
\hline $\begin{array}{l}\text { Breast Biopsy } \\
\text { No } \\
\text { Yes }\end{array}$ & $\begin{array}{l}13(76.47) \\
04(23.53)\end{array}$ & $\begin{array}{l}52(86.67) \\
08(13.33)\end{array}$ & 0.30 \\
\hline $\begin{array}{l}\text { Surgical removal } \\
\text { performed } \\
\text { No } \\
\text { Yes }\end{array}$ & $\begin{array}{l}\text { I6 (94.12) } \\
01 \text { (05.88) }\end{array}$ & $\begin{array}{l}52(86.67) \\
08(13.33)\end{array}$ & 0.39 \\
\hline $\begin{array}{l}\text { Pathological finding of } \\
\text { surgically removed } \\
\text { masses } \\
\text { Benign } \\
\text { Malignant }\end{array}$ & $\begin{array}{c}0 \\
01(100.00)\end{array}$ & $\begin{array}{l}07(87.50) \\
01(12.50)\end{array}$ & 0.04 \\
\hline
\end{tabular}

Abbreviation: MRI, magnetic resonance imaging.

and its association with many cancers has been well established in the literature. ${ }^{12}$

Increasing parity in our study was a protective factor against breast masses. In line with this finding, Odedina et al (2018) reported that females with more than two pregnancies had lower odds for breast disorders than those with fewer pregnancies. ${ }^{5}$ Increasing the number of deliveries is a known protective factor for breast cancer among females in general. ${ }^{5}$ In our study, this protective factor was reported more frequently among younger females. History of breastfeeding is another known protective factor for breast cancer. ${ }^{13}$ In this study, this finding was reported more frequently in females younger than 40 years than their older counterparts. Family physicians should play an important role in encouraging this healthy practice among their patients.
Gharekhanloo et al (2018) conducted a study among 203 females and reported that the most common location of both benign and malignant breast masses detected on ultrasound was the upper outer quadrant. ${ }^{2}$ However, the current study revealed that overlapping lesions were the most common site of breast masses, followed by the upper outer quadrant.

Studies on sonographic characteristics of breast masses reported that certain findings in ultrasound were found to be associated with malignant diagnoses such as spiculation, hypoechoic lesions, taller than wide, microlobulations, calcifications, and posterior acoustic shadow. ${ }^{2,4}$ On the other hand, benign masses have certain features such as a well-circumscribed appearance, hyperechoic, isoechoic or mildly hypoechoic, ellipsoid shape, and absence of any malignant features. ${ }^{4}$ Due to the limited number of malignant lesions, where only 2 were found in this sample, it was not feasible to compare the ultrasound features with regards to the definitive benign/malignant diagnosis. However, examining ultrasound findings such as margin, texture, vascularity, calcification, and BI-RADS with patients' age groups, no association was found. Interestingly, the dimensions of the masses were larger in younger females. In addition, posterior acoustic enhancement was seen more frequently in older females. Although the posterior acoustic enhancement is seen with benign lesions, studies reported its occurrence in high-grade tumors. $^{22}$

Family physicians in our study referred more than half of younger aged females and all cases $\geq 40$ years to mammography. This is in agreement with the evidence that supported the family physician to request mammography as an initial imaging for females aged $\geq 40$ years old who present with a breast mass, and ultrasonography for females younger than 30 years. For females between 30 and 39 years old, there is no clear evidence to prefer one imaging over the other. However, many guidelines suggest evaluating this age group similarly to females older than 40 years old. ${ }^{23}$

Only a minority cases of breast masses were referred for MRI by the family physicians in our study, and no significant association was observed with the patient's age. A previous study demonstrated that breast MRI is considered a second-line investigation in patients with breast symptoms, and it is usually performed in combination with mammography or ultrasound, it is indicated in females with a high risk of ovarian and breast cancer and those with a personal history of breast cancer. ${ }^{6}$ 
Family physicians in our study referred a minority of patients with breast mass for biopsy, and no significant differences were noted with different patients' ages. Additionally, they managed the rest of the patients according to the BI-RADS categories. Evidence that focused on a diagnostic approach of breast masses in PHC settings encouraged the use of BI-RADS of ultrasound and mammogram to guide the family physicians' approach to these cases, in addition to clinical suspicion of the physicians. ${ }^{23}$ In a study that included 2400 females, aged between 40 and 70 years, from PHC centers in the United States from 1983 to 1995 , showed that $16 \%$ had breast symptoms, and breast biopsy was performed for $27 \%$ of cases which is higher than reported in the current study. ${ }^{24}$ Biopsies of breast lesions facilitate accurate diagnoses. However, their use may be minimized in benign cases with improvement in noninvasive imaging technology. ${ }^{2}$ Studies revealed that breast biopsy is associated with anxiety, even in females with low levels of stress. $^{25}$

Surgical removal of masses was performed in 9 patients only in this study, one patient was $<40$ years old and the final diagnosis was malignant, and 8 cases were older than 40 years of age where all were benign except for one malignant case. Although the association between the diagnosis of the mass and patient's age could not be proved due to a small number of patients, however, studies reported that benign breast lesions were detected more among young females, and most of the malignant breast masses were observed among older. ${ }^{2}$

A particular strength of this study is its uniqueness where to the best of our knowledge, most of the available literature has focused on tertiary care and breast cancer, and data on PHC centers are limited, especially in KSA. Additionally, collection of the data from the patients' electronic records could limit the risk of recall bias. Nonetheless, there were some limitations; this was a crosssectional study and temporality and causality could not be assessed. Additionally, the study was conducted in one institution with a relatively small number of patients, which may have affected the generalizability of the findings.

\section{Conclusion}

Breast masses were detected in approximately one-quarter of females who underwent breast ultrasound. Moreover, the majority of these cases were seen among females 40 years old and above. We found that there is a lower risk of breast masses on ultrasound in grand multiparous females. In contrast, a higher risk of breast masses was observed in females with a high BMI, early menarche age, and the clinical presentation of lumps. These results support referral for investigation when a female complains of a breast lump, especially in presence of other risk factors. Some protective factors were reported more frequently among younger females such as high parity and breastfeeding. On the other hand, higher BMI was seen more among those females. Family physicians have a vital role in society in health promotion and disease prevention, where they should encourage protective behaviors against the development of breast masses such as maintaining a normal weight and promoting breastfeeding which is crucial, especially for young females. Sonographic examined masses were larger in young females, and posterior enhancement of the mass was more reported in older ones. On the other hand, BI-RADs of the masses was not associated with the patient's age. We recommend more generalizable, multicenter studies, with randomly selected participants. Moreover, future qualitative studies to explore patient perspectives on referral for further investigations are also suggested.

\section{Abbreviations}

PHC, primary health care; GPs, general practitioners; BI-RADS, Breast Imaging Reporting and Data System; KSA, Kingdom of Saudi Arabia; IAU, Imam Abdulrahman Bin Faisal University; BMI, body mass index; SD, standard deviations; OR, odds ratio; CI, confidence interval.

\section{Acknowledgments}

The authors acknowledge the help of Dr. Abdullah H. Alreedy, Mr. Rayan A. AlMutairi and Ms. Janice Ivy Ocampo, Dr. Seereen R. Almuhaidib, Dr. Sarah M. AlQahtani, Dr. Sara A. Aljaafari, Dr. Shadan A. Aljarri, Dr. Alanoud S. Al Alhareth, and Dr. Rizam A. Alghamdi in the data collection process. The authors also thank Editage (www. editage. com) for English language editing. The content is under the responsibility of the authors and does not represent the views of Imam Abdulrahman Bin Faisal University.

\section{Disclosure}

The authors report no conflicts of interest in this work. 


\section{References}

1. Eberl MM, Phillips RL, Lamberts H, Okkes I, Mahoney MC. Characterizing breast symptoms in family practice. Ann Fam Med. 2008;6(6):528-533. doi:10.1370/afm.905

2. Gharekhanloo F, Haseli MM, Torabian S. Value of ultrasound in the detection of benign and malignant breast diseases: a diagnostic accuracy study. Oman Med J. 2018;33(5):380-386. doi:10.5001/omj. 2018.71

3. Smania MA. Evaluation of common breast complaints in primary care. Nurse Pract. 2017;42(10):8-15. doi:10.1097/01.NPR.0000524 661.93974.e8

4. Gokhale S. Ultrasound characterization of breast masses. Indian J Radiol Imaging. 2009;19(3):242-247. doi:10.4103/0971-3026.54878

5. Odedina SO, Ajayi IO, Adeniji-Sofoluwe A, et al. A longitudinal study of the prevalence and characteristics of breast disorders detected by clinical breast examination during pregnancy and six months postpartum in Ibadan, Southwestern Nigeria. BMC Womens Health. 2018;18(1):152. doi:10.1186/s12905-018-0647-4

6. Thomassin-Naggara I, Tardivon A, Chopier J. Standardized diagnosis and reporting of breast cancer. Diagn Interv Imaging. 2014;95(78):759-766. doi:10.1016/j.diii.2014.06.006

7. Kingdom of Saudi Arabia, Saudi Health Council. Saudi cancer registry cancer incidence report in Saudi Arabia. 2014. Accessed November 19, 2019.

8. Albeshan SM, Mackey MG, Hossain SZ, Alfuraih AA, Brennan PC. Breast cancer epidemiology in Gulf Cooperation Council Countries: a regional and international comparison. Clin Breast Cancer. 2018;18 (3):e381-e92. doi:10.1016/j.clbc.2017.07.006

9. Kingdom of Saudi Arabia. Ministry of Health. Guide of national breast cancer early detection program. Available from:https://www. moh.gov.sa/Ministry/About/Health\%20Policies/011.pdf. Accessed February 13, 2021

10. Kingdom of Saudi Arabia. Ministry of Health. Breast cancer early detection. Available from: https://www.moh.gov.sa/en/Ministry/ Projects/breast-cancer/Pages/default.aspx. Accessed February 13, 2021.

11. Alshahrani M, Alhammam SYM, Al Munyif HAS, et al. Knowledge, attitudes, and practices of breast cancer screening methods among female patients in primary healthcare centers in Najran, Saudi Arabia. $J$ Cancer Educ. 2019;34(6):1167-1172. doi:10.1007/s13187-018-1423-8

12. Alsolami FJ, Azzeh FS, Ghafouri KJ, et al. Determinants of breast cancer in Saudi women from Makkah region: a case-control study (breast cancer risk factors among Saudi women). BMC Public Health. 2019;19(1):1554. doi:10.1186/s12889-019-7942-3

13. Abulkhair OA, Al Tahan FM, Young SE, Musaad SM, Jazieh AR. The first national public breast cancer screening program in Saudi Arabia. Ann Saudi Med. 2010;30(5):350-357. doi:10.4103/0256-4947.67078
14. The government of Saudi Arabia national transformation program. 2016. Accessed November 15, 2019.

15. Arafah MA, Kfoury HM. Radiological tests versus pathological diagnostics: complimentary or antagonistic relationship? The experience of a tertiary hospital. Indian J Pathol Microbiol. 2017;60(3):365-370. doi:10.4103/IJPM.IJPM 3517

16. StataCorp. Stata Statistical Software: Release 16. College Station, TX: StataCorp LLC; 2019.

17. Al-Khamis NK. Low awareness of breast cancer and considerable barriers to early presentation among Saudi women at a primary care setting. J Cancer Educ. 2018;33(2):391-397. doi:10.1007/s13187-01 6-1119-x

18. Abdel-Aziz SB, Amin TT, Al-Gadeeb MB, et al. Perceived barriers to breast cancer screening among Saudi women at primary care setting. J Prev Med Hyg. 2018;59(1):E20-e9. doi:10.15167/2421-4248/jpmh 2018.59.1.689

19. Al-Zalabani AH, Alharbi KD, Fallatah NI, Alqabshawi RI, AlZalabani AA, Alghamdi SM. Breast cancer knowledge and screening practice and barriers among women in Madinah, Saudi Arabia. $J$ Cancer Educ. 2018;33(1):201-207. doi:10.1007/s13187-016-10 57-7

20. Koo MM, von Wagner C, Abel GA, McPhail S, Rubin GP, Lyratzopoulos G. Typical and atypical presenting symptoms of breast cancer and their associations with diagnostic intervals: evidence from a national audit of cancer diagnosis. Cancer Epidemiol. 2017;48: 140-146. doi:10.1016/j.canep.2017.04.010

21. González-Pérez B, Salas-Flores R, Sosa-López ML, et al. Female breast symptoms in patients attended in the family medicine practice. Rev Med Inst Mex Seguro Soc. 2013;51(5):558-561.

22. Wojcinski S, Stefanidou N, Hillemanns P, Degenhardt F. The biology of malignant breast tumors has an impact on the presentation in ultrasound: an analysis of 315 cases. BMC Women's Health. 2013;13: 47. doi:10.1186/1472-6874-13-47

23. Salzman B, Collins E, Hersh L. Common breast problems. Am Fam Physician. 2019;99(8):505-514.

24. Barton MB, Elmore JG, Fletcher SW. Breast symptoms among women enrolled in a health maintenance organization: frequency, evaluation, and outcome. Ann Intern Med. 1999;130(8):651-657. doi:10.7326/0003-4819-130-8-199904200-00005

25. Hayes Balmadrid MA, Shelby RA, Wren AA, et al. Anxiety prior to breast biopsy: relationships with length of time from breast biopsy recommendation to biopsy procedure and psychosocial factors. J Health Psychol. 2017;22(5):561-571. doi:10.1177/1359105315607 828
International Journal of General Medicine

\section{Publish your work in this journal}

The International Journal of General Medicine is an international, peer-reviewed open-access journal that focuses on general and internal medicine, pathogenesis, epidemiology, diagnosis, monitoring and treatment protocols. The journal is characterized by the rapid reporting of reviews, original research and clinical studies across all disease areas. The manuscript management system is completely online and includes a very quick and fair peer-review system, which is all easy to use. Visit http://www.dovepress.com/ testimonials.php to read real quotes from published authors. 